\title{
Challenges to globalization and its impact on prevailing international liberal order
}

\author{
Muhammad Adeel Khan*| Manzoor Ahmad Naazer | Amna Mahmood \\ Department of Politics \& International Relations, International Islamic University, Islamabad, Pakistan. \\ *Corresponding Author Emails: mak.y@ hotmail.com|dradeelkhan2@gmail.com
}

\begin{abstract}
:
Challenges to globalization have grave implications for the worldwide liberal order that emerged with the end of the cold war. These challenges began to ascend from the West. The occasions like Brexit, ascent of radical rightist political groups in Europe, recognition of isolationist policies, choice of former US President Donald Trump (Originator of isolationist policies), and the strive towards confinement of manufacture and services have altered the contours of global liberal order. The objective of this study is to find the factors that prepared ground for anti-globalization accounts as well as to discover its effect on the global liberal order by applying the content analysis method. This study used qualitative methodology utilizing both primary and secondary data i.e., government documents, annual reports, speeches of leaders, books, journal articles and newspapers etc. Findings of the study concludes that anti-globalization narratives are translating into the electoral processes, progressing hyper-nationalism over liberal order; multi-polarity above Uni-polarity; and Isolationism above free market economy. All such changes have critical repercussions for the global liberal order, hence, should be observed cautiously. If the pattern proceeds, the world pioneers ought to think about modifying the worldwide associations, alliances, as well as national security procedures.
\end{abstract}

Article History

Received:

August 13, 2020

Last Revised:

June 2, 2021

Accepted:

June 3, 2021

Published:

June 22, 2021

Keywords: globalization, anti-globalization, WTO, international trade, European Union, Brexit, isolationism, protectionism, nationalism, world order, uni-polarity, multi-polarity.

How to Cite: Khan, A. K., Naazer, M. A., \& Mahmood, A. (2021). Challenges to globalization and its impact on prevailing international liberal order. Liberal Arts and Social Sciences International Journal (LASSIJ), 5(1), 372-385. https://doi.org/10.47264/idea.lassij/5.1.24

Publisher's Note: IDEA PUBLISHERS (IDEA Journals Group) stands neutral with regard to the jurisdictional claims in the published maps and the institutional affiliations.

Copyright: ( 2021 The Author(s), published by IDEA PUBLISHERS (IDEA Journals Group). This is an Open Access article published under the Creative Commons Attribution-NonCommercial 4.0 International License (http://creativecommons.org/licenses/by-nc/4.0/) 


\section{Introduction}

By the end of the Twentieth Century when cold war came to an end, another period was incepted that of neo-liberal world order which further advanced the process of globalization. This era saw monstrous improvements in the advancement of globalization through the support of Washington Consensus, IMF and World Bank crediting projects, WTO and international trade alliances (McGrew, 1992). Essentially, International visa systems were mollified and individuals to individuals contact were encouraged. Aside from that improvement in information technology resembled what tops off an already good thing for globalization; it transformed the world into a global village. Owing to these turns of events, world set up it's political, financial and security framework on the principles of globalization (Ritzer, 2015).

Later on, the course of globalization became the source of many problems due to its massive shortcomings (Chase-Dunn, 2005). As of late, the world has witnessed an intensifying reaction against the progression of globalization. Developing isolationism in the world, weakening of the WTO's dispute settlement framework, protests against worldwide monetary institutions, and articulations against financial globalization of the IMF are some of its prominent examples. Similarly, political globalization is additionally encountering push back as electors and legislators are criticizing the limitations international organizations put on public sway. International institutions as assorted as the International Criminal Court, the World Health Organization, or the European Union have lost significant member nations, and drives for new peaceful accords have been difficult to finish up. At long last, there is additionally developing reaction against cultural and social globalization, for example, antiimmigrant response, anti-tourism contests, as well as an overall worry about the loss of local culture, values and traditions in a globalized world (Walter, 2021).

A persuasive narrative holds that challenge to globalization is entrenched in the mass public, where an emerging percentage of losers of globalization progressively lash out against globalization in its various appearances. The most definite and weighty instances of this eminent backlash are the political achievements of nationalist applicants, for example, Jair Bolsonaro or Donald Trump and the Brexit choice vote (Walter, 2021).

In one of the publications by The Washington Post in 2017, a renowned American political scholar 'Francis Fukuyama' communicated profound apprehension about the threat to the international liberal order which originates from below the surface of global politics. He argued that the liberal movement throughout the West will rapidly fade away. An approaching political crisis indicated by the reaction of right and left wing-nationalisms on the two sides of the Atlantic combined with complaints over multiculturalism and immigration will intensify inside strains inside democracies delivered by globalization, speed up the erosion of political institutions, and destroy majority rule standards (Rewizorski, 2021).

Anti-globalization activists contend that contemporary globalization rehearses has brought about irrational and crushing conditions in many countries. They uphold those international partnerships have developed in excellence, influence, and treasure, while producing countries keep on battling with frantic neediness. Globalization has driven plentiful organizations to employee low-wage laborers in developing countries, eliminating employments in industrialized nations. Environmental insurance has similarly been relinquished for the sake of globalization (Detraz, 2009). Enormous partnerships have stayed away from the stringent 
guidelines in industrialized countries by migrating manufacturing plants in less-controlled nations (Encyclopaedia, n.d.).

The anti-globalization movement includes ordinary and self-governing worker's organizations, craftsmanship assemblies, landless laborers' gatherings, indigenous gatherings, communists, socialists, rebels, Trotskyists, portions of the ecology growth as well as the women's activists, Third World activists, social equality gatherings, students, religious gatherings, basic freedoms gatherings, bunches from the joblessness movement, conventional left-wing parties, basic scholarly people, etc. from everywhere on over the world (Fuchs, 2015). It merits referencing that these protestors are not really against worldwide cooperation and integration however they are either the victims or people in question or, dread of its results, for example, structural adjustment programs, migrations, cultural assimilations, loss of jobs, and inequality etc. (Guibernau, 2010).

All of this has led to occasions like Brexit, the ascent of chauvinist, election of former U.S. President Donald J. Trump (profounder of nationalist policies), anti-emigrant attitudes, BRICS nations rise and the emergence of new powers on the world map (Khan, 2016). These occasions are not so straightforward but rather they are the outflows of innate shortcomings in the post- Cold War model, which was encapsulation of neo-liberal economy, Uni-polarity and multilateralism. Because of absence of status concordance between new turns of events and existing constructions, westerners began feeling vulnerability about their future, so they rebelled against the existing structure, through casting a ballot, social media and different methods for articulation (Hannah Fuchs, 2017).

This study is intended to find out the real factors that prepared the ground for antiglobalization waves and movements as well as it will evaluate the impacts of antiglobalization waves on the international liberal world order. The principal objective of this study is to answer the questions like, what are the factors responsible for anti-globalization waves and what are its impacts on the existing international liberal order. The study has a great significance and is important both in theoretical and practical terms. Backlash in globalization will, necessarily, have genuine ramifications for the world security infrastructure. We are noticing that multilateral agreements are either annulled or renegotiated. The balance of power amongst key actors is exposed to the structural loopholes present in the international system. Today, there are certain unstable regions like Afghanistan, South China Sea, Eastern Europe, as well as Middle East where the major powers of the world are on the threshold of limited war with each other aimlessly. UN part, though still imperative, but limiting to non-security matters. Likewise, neither American people nor rulers are prepared to spend more on keeping up worldwide harmony. Thus, there may be a power vacuum in global security field. Realizing the underlining causes and expected effects is vital for running worldwide system easily. Apart from this, any incongruity in globalization is a grave concern for both academicians and practitioners of worldwide political economists as well. The topic is also noteworthy in a sense that it fused two distinct ideas of globalization and International liberal order. Work has already been done on both the topics but separately and on its different dimensions. The exquisiteness of this exploration is that it combined both and inter-relates it into present-day events.

As the nature of the concerned research topic is based on a qualitative methodology, the study is designed to use a method known as content analysis. Content analysis is a research method used to identify patterns in recorded communication. As per the nature of the concerned 
research topic, qualitative data will be used in this research study. Both primary as well as secondary data will be utilized for making deductions concerning the relevant issues under the theme. The remaining structure of the study will include: Theoretical Framework, Literature Review, Methodology, Findings, Conclusion, and References.

\section{Literature review}

In order to reach pertinent substance matter, a lot of books, periodical, research papers, Journals, surveys, reports, videos, News Papers, interviews, were being studied. As the theme of the said study is so much multi-dimensional, works related to theories of international relations, fresh and historical occasions, as well as literature concerning globalization along with anti-globalization waves was deeply studied. To understand the essentials of globalization the book "Globalization: A Very Short Introduction" by Steger (2003) was counseled. This book was extremely useful in understanding the very nuts and bolts of globalization, for example, its history, various aspects, such as social, economic, political and ideological, eventual fate of globalization and difficulties in its manner. This manuscript was useful in relating globalization to migrations, international trade, financial crisis and disparity.

Likewise, work by Barry Buzan was very useful for understanding global change. For instance, in one of his books "The Global Transformation History, Modernity and the Making of International Relations" he gave significant knowledge about the advancements occurred in international relations, equally in theory and practice, ever since biggening of nineteenth century and a review of great powers game. In addition, he dissected philosophies of advancement inside and out and related it to the modern age nation state structure. Over all, it was pertinent to my exploration explicitly in the context of macro transformations as well as the changing methods and modes of power and its connection to the structural and technological modifications (Buzan, 2015).

Alongside these documents, the book which delivered alternative viewpoint, such as discontents with globalization, is "Globalization and its Discontents" written by Stiglitz (2002). He argued in his book, on the basis of his personal experience that advanced or developed countries particularly US and EU exploit the unindustrialized or developing and underdeveloped states for their relative gains since they have the resources, tranquil access to information as well as veto power in worldwide monetary institutes. Likewise, he says that there are certain flaws in the existing structure which harvests rebellious thoughts in those who are the victims of these unfair policies.

The record that helped further and utilized for this exploration were "Will Technological Convergence Reverse Globalization?" composed by Hammes (2016). Similarly, Hammes, "Adding insult to injury how bad policy decisions have amplified globalization's costs for American workers" and likewise an inquiry report by the independent commission on multilateralism titled as "The Impact of New Technologies on Peace, Security and development" provided enhanced insight.

Various patterns are easing back, and may even be turning around, globalization throughout the following decade or two. Production and services, driven by new innovations, are drifting toward local manufacture. For monetary, technical, and ecological reasons, new energy production is currently commanded by local sources, sun powered, wind, hydro, and frocked natural gas. To satisfy an expanding need for fresh, natural nourishments, firms are setting up 
indoor homesteads in urban areas over the developed world to cultivate and sell food locally (Hammes, 2016).

Globalization as an ideology debilitating country states, subverting democracy as well as sovereignty, corroding worldwide cooperation administrative mechanisms and deceiving 'individuals' with the unfilled guarantees of the elitist structure of worldwide financial governance. The nationalist reaction against globalization and political elites can escalate the creation of new political cleavages, discourage or forestall compromises, or sabotage the authenticity of political institutions. Nationalists may target the set up global order and liberal democracy (Rewizorski, 2021).

Throughout the globe, governments are moving all the while to restrict the force of technological organizations with a desperation and expansiveness that no single industry had encountered previously. In the United States as well as in Europe, it is a great worry that technological organizations are smothering rivalry, spreading falsehood and disintegrating security; in Russia and somewhere else, it is to silence protest activities and fix political control; in China, it is considered as some of both (Mozur, 2021).

Austeritarianism could advance towards oppressive neo-radicalism, with identitarian as well as securitarian philosophies, conveyed by social groups that the dread of downsizing and frailty are pushing to the extreme right, parting space for manoeuvre to fundamentalist groups. Forceful patriotisms are in all-out aggressive mode, oppressive regimes are replicating and in excess of a billion people live in the disaster areas or war zones (Hopgood, 2013). Then again, revolutionary movements are showing a craving for extremist change: the women's association is addressing millenary influences; the environment earnestness movement is exploding inevitabilities about the origination of development dependent on productivist expansion; the movement against prejudice and discrimination, following the case of developments, for example, Black Lives Matters, the Brazilian Afro-women's activists, and native people groups, is featuring the incomplete decolonization (Massiah, 2021).

There is a far and wide view that the impacts of globalization, including unreasonable worldwide trade, capital portability, and repeating economic and monetary crises, may prompt increased joblessness, decreased wages, slowing down growth rates and scarcity, which stirs radicalization and dissatisfaction. The Central Europe, which is also considered as the Eastern frontier of the West is suffering disparity and financial hardship as a victim of globalization, certainly making rich justification for the ascent of tyrant populism (Rewizorski, 2021).

\section{Theoretical framework}

Defining a particular theoretical context for an exploration bears so much importance as it relates the examination with prevailing literature and governs suitable direction. This study will, be tried to, be built on the foundations of Neo-Realism and constructivism in order to get pluralistic results.

\subsection{Constructivism}

Logically, Constructivism is the acknowledgment that the truth or reality is a construction of human insight exuding from one's understanding and socialization in reality. It discovers its viewpoint about the idea of knowledge, particularly, it offers an ontological position. 
Constructivists esteem reality as a development of human psyche, and henceforth, the truth is seen to be subjective. Besides, this philosophical methodology is firmly connected with logic and relativism. Basically, it centres on the process of perception and learning through experience (Jackson, 2019).

In terms of international relations, constructivism proposes that significant features of international relations are historically and socially built. Worldwide politics are neither unavoidable outcomes of human nature nor other indispensable features of world politics. It was Nicholas Onuf who devised the term "constructivism" for the first time in international relations (Checkel, 2017).

This study generally follows constructivist/interpretivist approach, where it will dissect the development and deconstruction of the discourse of globalization as well as emergence of new global patterns mostly through qualitative methods. This study will examine how the discourse of globalization was developed through historical cycle. Likewise, it will check how and why globalization is disintegrating and what its impact on the International liberal order is.

\subsection{Neo-realism}

Neo-realism, which is additionally called structural realism, is an international relations hypothesis that trusts power as the centre component in worldwide relations. The term was first coined by Kenneth Waltz in his 1979 book, "Theory of International Politics" (Waltz, 2010). Neo-realism emerged from American order of political theory, and reformulates the traditional realism. Traditional or classical realism essentially described the intrigues of IR as being focused on the nature of man, and in this way, subject to the sense of self or ego and opinions of the world heads (Sorensen, 2010). Nonetheless, neo-realist scholars contend that it is structural limitations not selfishness, strategy or motivation which will decide conduct of a state in global relations. Neo-realism which is also called structural realism contends that the nature of the international structure is detailed by its organization, anarchy, and by the allocation of capabilities. Inside this anarchical worldwide structure there is no central power (Fischer, 2012). Every independent state looks for its own interest through self- help. Each state is expected to make sure its own survival as this is a prerequisite to chase other goals. States can never be certain of other states' future intents, so there is a lack of trust among states. Power gain by one state is considered warning by the other state for own survival (Pashakhanlou, 2014).

The structural variations of capabilities restrict collaboration between states through fears of relative gains made by other actors, and the likelihood of dependence on other states. The goal and relative capabilities of every state to augment relative power restrain each other, causing 'balance of power', which shapes international relations. It may also lead to the 'security quandary' that every country faces. To coup with this issue, states either raise their power through increasing economic development or expanding military expenses or making alliances (Pashakhanlou, 2014).

The entire examination will also be seen in the crystal of neo-realism inferable from its relationship with this exploration. As Neo-realism is the most pervasive theory in international relations examining global structure be its political, or financial or security structure, so it is more applicable to the said examination. Social and political variances occurring at societal level translates into national level, where it makes ground for global turns of events. 


\section{Research methodology}

Methodology is the core of an exploration or research study, which marks the structure of the study. It is called as scientifically planned or codified process to test theories. Keeping in view the larger scope of the subject it seems appropriate to adopt qualitative and interpretive method of research. Subsequently, it will authorize the investigator to examine in-depth reasons that would enhance the reliability of the academic research.

As the nature of the concerned research topic is based on a qualitative methodology, the study is designed to use a technique known as content analysis. Content analysis is a research technique or method used to identify patterns in the recorded communiqué. To conduct content analysis, data is collected systematically from a set of texts, which can be on paper, verbal, or visual i.e., Books, newspapers and magazines, Speeches and interviews, Web content and social media posts, Photographs and films etc. The purpose of content analysis method is to organize as well as elicit meaning from the information collected and to draw accurate conclusions from it.

Both primary and secondary data will be utilized for making deductions regarding the relevant issues under the topic. The primary data will be based on the government documents, foreign affairs records, annual reports, statement and speeches of various leaders of the states, Charters/Declarations, and Joint Press Releases etc. All the secondary sources available in the form of books and articles published in various journals, newspapers and magazines, online sources, television and commentaries will also be utilized during the study.

The researcher will analyze the collected primary and secondary data using the models of Constructivism and Neo-Realism. It will help the researcher to find out all the factors or causes responsible for anti-globalization waves and will assist in evaluating its impacts on the postcold war liberal order.

\section{Discussion and findings}

As of late, the world has witnessed a mounting reaction against globalization. The expanding impact of anti-globalization narrative has brought about more isolationist, protectionist and patriotic policies, some of which generally undermine the central ideas of the contemporary worldwide order. Globalization backlash is driven by both material and non-material causes and these causes coincide, cooperate, and intercede one another. The fallouts are formed by the reactions of cultural actors, national governments, and worldwide policymakers.

\subsection{Causes of globalization backlash}

The factors accountable for anti-globalization sentiments are given below:

\subsubsection{Economic reservations}

The backlash in the process of globalization is on its way, predominantly, in the aftermath of the International monetary crisis, this process boosted (Roubini, 2009). Worldwide trade is easing back, particularly when contrasted with the development in GDP. New monetary actors arising and consequently, the practices and patterns of trade are likewise changing alongside financial and political overall influence. There is a widespread view that the process of 
globalization is prompting unfair global trade, capital mobility, profit-oriented world order, as well as frequent economic and monetary crises, which thusly is prompting increased unemployment, stalling development rates, reduced wages, as well as dispossession. All of this stir disappointment and radicalization. Nationalist parties are mainly motivated by dread and monetary anxiety. In France, Italy as well as in Austria a majority of respondents recognize globalization as a threat and demonstrate the utmost level of economic apprehension at 54, 45 and 55 per cent, correspondingly (Rewizorski, 2021).

Today, the nationalists or right-wing populist parties attack globalization in three ways. Firstly, they view globalization as a source of financial anxiety prompting unfair trade and trade stuns accompanied by movements of imported goods harming local businesses. For instance, the Germans who export unemployment to adjoining nations by establishing their production plants and corporate retailers, similarly, in the shape of NAFTA agreement, where Mexicans take jobs away from Americans. Secondly, they are against liberalized money and investment as it leads to economic crisis which sabotage trust in business sectors, state organizations, and increment financial and political uncertainty. At last, immigration is portrayed as a forerunner of adverse labour market influences, particularly for less-skilled individuals, which nationalist parties exploit by censuring the elites for the crisis and promising transient insurance (Rewizorski, 2021).

The damages of globalization are additionally felt in the developing nations, which could have an exceptional impact over the political dependability of organizations through an expanding feeling of fierceness in the working class and lower-white collar classes, who have witnessed their income and position debilitating all the while, and their upward advancement is ruined (Bivens, 2017). The sentiment of anger has started to change into electoral route. People in developing and developed countries expressed their concerns regarding free trade agreements that lead to outsourcing of jobs, destruction of native cultures and traditions, crowding out industries, as well as declining tax returns.

In locales that face greater trade contest with China as well as other low-wage nations, extremist right wing and conservative parties are more popular and successful. In the United States 2016 elections, Donald Trump got significantly more votes in the areas, where support for strict immigration policies as well as protectionism was higher, and lawmakers from these locales supported more isolationist trade policy recommendations (Kimball, 2014). In like manner, Brexit-referendum in 2016, the "Leave"- vote was altogether higher in networks with a more noteworthy openness to the "China stun" as well as rising migration levels. Monetary globalization likewise matters, extremist right-wing parties tend to flourish in the fallout of worldwide monetary crisis that hit communities more earnestly by global monetary stuns and the crisis show a more grounded support for nationalist parties. Similarly, the impacts of trade stuns on voting conduct have been built up by the worldwide monetary crisis as well as the euro crisis (Walter, 2021). Trade has solid distributive outcomes, produces grievances and assists inequality in both developing and developed nations, and this examination propose that inexorably, this is met with a backlash response.

\subsubsection{Technological progression}

Anti-globalization waves are defended and supported by the individuals who have lost from hyper-globalization especially the white workers. Such types of workers are less skilled as well as less educated. As indicated by reports, these workers became less valuable for various 
businesses as a result of advancements in present digital technologies as well as computerization of the large portion of industries and businesses. The combination of latest technologies like AI (Artificial Intelligence), robotics as well as 3D technologies are quickly changing the generation or production procedure of goods. The automated industry currently needs just a couple of men to regulate mechanical production. Klaus Schwab viewed these developments as fourth Industrial revolution, which is involved in blurring the lines between the digital, physical and biological spheres. The scope and intricacy of these progressions stimulated the transformation of entire structure of production and administration (Klaus, 2016). An Oxford study has assessed, that around 35 percent of the UK workers along with the 47 percent that of USA may possibly lose their jobs to technology over the accompanying two decades (Hammes, 2016).

Indeed, the IMF issued a report in 2019 that argues that the influences of modernization and technology on local work markets are considerably more inescapable and enduring than trade stuns. These patterns have been increased by a decline in income, corporate and wealth taxes cultivated by monetary globalization, which have added to an ascent in inequity as well as limited the state's capacity to remunerate the losers of these progressions. These major monetary changes have together expanded local discrepancies as well as socio-economic disparities, which have given a favourable ground for globalization backlash (Walter, 2021).

\subsubsection{Media revolution}

Media globalization has an adverse consequence, harming universal culture, worldwide interrelationships and society overall. This globalization has led to the development of antiglobalization sentiments throughout the world. Main stream media as well as social media not only provides a stage to the international anti-globalists but also to the sufferers of globalization so that they can express their emotions, which results in voting as well as in developing hatred against globalist policies. In $21^{\text {st }}$ century, majority of the successful movements are initiated and controlled through social media. Indeed, even common masses take part in political discussions and communicate their indignation regarding the effects of unrestricted trade and massive import policies that are accountable for their low wages. Of course, there were structural flaws in the process of globalization that spurred the antiglobalization sentiments but new technologies in the shape of electronic, social and print media acted as a catalyst. Another influx of hyper-nationalism arose in the period of posttruth global politics further subsided globalization. The process of globalization in the period of fake-news turned out to be more convoluted as it disturbed a central component of diplomacy and global politics. Counterfeit charges and baseless claims garble diplomatic relations among the states and lead to political and military skirmishes. For example, fabricated claims mingling on social media about the cash extorted from the United Kingdom by the EU expedited the drive for Brexit, which led to unrest in Europe as well as in rest of the world. The likelihood of interfering in the national elections likewise has significant geopolitical and security insinuations. US elections are more often the victim of such media strikes. The broadcasting of false news can bring irreversible damage to the basics of the

global liberal order. It will additionally hone polarizations, degenerate intellectual veracity and harm the system of democracy (Al-Rodhan, 2017).

\subsubsection{Cultural apprehensions}

Globalization unswervingly influences political, cultural, economic and technological 
boundaries of the world order. Owing to broadened nature of every one of the diverse perspectives, which are even interlinked to one another, globalization also shadows its impact, which causes a multifaceted association of all the patterns. Globalization influence on culture has consequences for nations, societies as well as organizations. Globalization encourages flow of culture and national practices athwart borders. The course of globalization is homogenizing certain values, beliefs and thoughts engendering in a worldwide social and dialectal commonalities. Numerous countries and ethnic minorities are truly worried about the conceived annihilation of their local cultures and dialects. U.S.A and Europe both opened up their borders for international trade and immigrants in the post-World War 2 period, however, both these initiatives led them to several problems. The measures that they took to strengthen the course of globalization not only threatened their local labour, products and markets but were also responsible for waning of identity, and cultural standards as well as bringing in terrorism, extremism, racism and intolerance. All of this gave birth to severe opposition in the west against globalization (Bivens, 2017).

Some authors contend that non-economic aspects such as cultural or social concerns, ideology, identity or apprehensions related to sovereignty are considerably more significant drivers of the globalization reaction than material apprehensions. For instance, resistance to monetary globalization is more grounded among people holding traditional authoritarian, isolationist and nationalist standards and attitudes or those worried about the adverse socioeconomic impacts of trade. Resistance to socio-cultural and political globalization is identified with apprehensions about limitations on national sovereignty and a social reaction against neoliberalism and mainstream culture (Zumbrun, 2016). Cultural, social and economic alterations can likewise generate anxieties that fuel anti-globalist, anti-immigrant, and isolationist attitudes among the individuals who see their subjective communal wellbeing threatened. These progressions in non-material mentalities thusly then fill in as general reasons for voting conduct. Simultaneously, social values can deliver a prism through which financial improvements are deciphered.

In Hungary and Poland, major nationalist parties like Fidesz and PiS are concerned about the nationalist sentiments (traditionalism) and ideological as well as identity related threats. The major apprehension for both is articulated in a belief that the multiculti West is foisting Muslim immigrants on their motherlands in order to abolish their native identities (Rewizorski, 2021).

\subsection{Anti-globalization sentiments, impact on prevailing international liberal order}

\subsubsection{Liberalism to hyper-nationalism}

Recent patterns across America and Europe recommend that the international liberal order is progressively altering. The world is moving away from globalized liberal order towards isolationism and nationalism (Flecker, 2016). The progressions are obvious in the ascent of hyper nationalism following the Brexit plebiscite of 2016 and ensuing departure of the UK from European Union, the Catalonia freedom poll of 2017, New Caledonia plebiscite of 2018 in France, as well as weakening of multilateralism and increase in trade protectionism and isolationism. Additional signs of transformation embrace the United States new immigration guidelines and the planned wall on the United States/Mexico border, the choice of the US President Donald Trump (Profounder of isolationist policies), a strategic change in U.S. policy from openness to patriotism and isolationism (Buy America and hire America), plus the exit of 
the United States from the 2015 Paris accord on climate change. All of this shows that antiglobalization sentiments are strengthening day by day and posing serious threats to the prevailing worldwide liberal order. Spence and Hu (2017) suggest that the Brexit choice represent the victory of anti-globalization narratives, nationalism, protectionism and nativism, proposing that each and every aspect of the global liberal order is under attack (Amadi, 2020).

A developing swell of outrageous chauvinism, or hyper nationalism, has become a dare to central democratic standards. The inability to effectively complete the Madrid climate conference of 2019 or the challenges of concocting European Union wide reactions to the refugee, euro and COVID-19 crises are some of its examples. Dani Rodrik proposes that the nationalist backlash against globalization and political elites can deepen the making of new political cleavages, discourage or avert compromises, or challenge the legitimacy or authority of political institutions. In his opinion, nationalists may attack liberal democracy as well as the well-known universal order (Rewizorski, 2021).

\subsubsection{Free market economy to protectionism or isolationism}

Rightist and nationalist politics can pose greater economic and financial risks by challenging the existing structures, particularly those involving worldwide trade. West is responding to the worldwide economic breakdown by embracing protectionist policies. U.S. is following the policy of 'buy America and Hire America', enforces limitations on the use of non-American material in all the public works programmes, similarly, banks and firms are facing enormous restrictions on employing foreign workers as well as by receiving rescue funds from the government for different purposes. European governments as well pursue protectionist and nationalist policies. Governments driving funds into banks to retain them solvent are asserting that those moneys be used nationally. The French administration compelled the auto industry to shrink manufacture abroad and upsurge manufacture in France. Other European nations have propositions to increase agriculture grants. Likewise, UK left the European Union while U.S. has withdrawn from the Trans-Pacific Partnership (TPP) as well as want to renegotiate and revise the North American Free Trade Agreement (NAFTA) (Blecker, 2017).

The call for protectionism will be fortified as a response to worldwide overproduction. To evade closure of industries and businesses, import taxes are being raised. More nations are legislating for guarding their native industries and businesses whether they produce more costly and fewer competitive items. Local manufacture is getting more mainstream as it is more affordable. In the near future, these patterns will bring about the limitation of production, energy, services, as well as food production. Public laws will turn out to be stricter on liberal democracy and welfare state system (Ikenberry, 2018). Individuals in the west are increasingly disappointed with growing discrimination and increasing unemployment. The move from globalism towards localism in manufacture will alter the global security framework. The goal of these protectionist mottoes and policies is to preserve capital and maintain jobs inside national boundaries as well as to help the local businesses (Amadi, 2020).

\subsubsection{Uni-polar world to multi-polar world}

'Qingguo Jia' from China contends that the post-World War II liberal order led by United States is undoubtedly in serious trouble. Emerging from World War II as the preeminent world power, the United States was instrumental in creating a new international order, primarily because it realized that shaping the rules, norms, and institutions of the new era would protect 
its global interests. In the post-World War II period, United States of America did three things primarily: conserved and improved its wartime structure of military alliances, advanced partnerships with different states, and established a group of worldwide institutions and systems under the umbrella of United Nations with the aim to extend the political, social, economic and military cooperation among different countries of the world, that in turn boosted the process of globalization. This international liberal order is today in serious trouble (Paul \& Stares, 2020).

The will of the United States to uphold world order has considerably deteriorated mainly under the Trump administration. Though, every former U.S. President placed the United States interests first, yet, the Trump administration has gone considerably further both in rhetoric as well as in action. U.S. has shoved aside from its leadership duties in world undertakings and surprisingly made moves that have sabotaged existing worldwide organizations, counting pulling out from the Trans-Pacific Partnership (TPP), UN Educational, Scientific, and Cultural Organization (UNESCO), as well as the Paris Treaty on climate change. U.S. has taken onesided actions against other states on trade disagreements, consequently, dared the World Trade Organization (WTO) rulebooks. It is likewise becoming more hesitant to tolerate the costs of world leadership. U.S. is no longer keen and capable to withstand a global order bigger than itself plus no one else is in a position to completely step into the void, therefore, the world has entered into a multipolar order (Paul \& Stares, 2020).

The worldwide dispersal of influence is inevitably shifting with the ascent of novel powers like China, Russia, France and India etc. as well as powerful non-state actors, such as multinational businesses and worldwide terrorist organizations. Similarly, the advantages of the U.S-led order and, in specific, the numerous worldwide settlements that the U.S. has supported to allow the world to the unrestricted flow of goods, ideas, services, as well as people, no longer appear so encouraging not least to the countless Americans whose livings have hurt as a consequence. This move has caused a public backlash against globalization not only in the United States but also in many Western countries that has demonstrated itself in more nationalist and inwardlooking strategies. As a consequence, the political will to guard the liberal order is in short supply (Paul \& Stares, 2020).

\section{Conclusion}

This study has deliberated the complicated association of anti-globalization refluxes and its impact on the prevailing worldwide liberal order. The waves of globalization are stirring in the reverse course from the global periphery to the global core. Instead of struggle for worldwide interconnectedness, the West is moving towards isolationism and enforcing restrictions on trade and migration, embracing protectionist policies, repatriating earlier deserted industries, and letting the ascent of nationalism. Lately, the world has witnessed a growing backlash against all three aspects of globalization: political, economic, as well as socio-cultural globalization. Both material and non-material sources drive the globalization backlash. The criticism demonstrates itself in the democratic victories of globalization-skeptic groups, in a more undesirable tone and biased discourse over globalization, as well as an increase in strategies designed to halt or restrain monetary, political and cultural globalization.

Individuals respond to financial disturbances by deciding in favour of nationalist parties as well as by backing up the rightist movements. They read globalization as a thick dogma, debilitating nation states, corroding worldwide cooperation as well as governing frameworks, subverting 
democracy and sovereignty, and deluding 'individuals' with void guarantees of an elitist structure of worldwide (monetary) administration. As per Karl Marx, 'Every development sets a stage for other development.' The process of globalization carried many flaws, shortcomings and contradictions in itself. It mostly pursued the interests of the few (western powers), exploiting the interests of a weak as well as the developing countries. In this way, it paved the way for counter narratives to develop.

There is a lesser regard for the international institutions and international law, as witnessed in the case of Syria, Paris treaty, Iran nuclear deal, and South China Sea etc., hence, this disregard to international institutions and treaties clearly depicts the backlash against globalization. International liberal order is eroding (rise of trade wars, annulment of treaties, expansion of technological wars etc.) and every powerful state is coming with its own version of globalization. For instance, China's vision of 'One Belt One Road', Russia's struggle for 'Euro Asian Economic Bloc', rise of 'Asian International Investment Bank' and expansion of the 'BRICS' countries influence, all point out towards the rise of a new worldwide order.

\section{References}

Amadi, L. (2020). Globalization and the changing liberal international order: A review of the literature. Research in Globalization, 2, 100015. https://doi.org/10.1016/j.resglo.2020.100015

Al-Rodhan, N. (2017). Post-truth politics, the fifth estate and the securitization of fake news. Global Policy, 1-8. https://www.globalpolicyjournal.com/blog/07/06/2017/posttruth-politics-fifth-estate-and-securitization-fake-news

Bivens, J. (2017). Adding insult to injury. Economic Policy Institute.

Buzan, B., \& Lawson, G. (2015). The global transformation: history, modernity and the making of international relations (Vol. 135). Cambridge University.

Buzan, B., \& Lawson, G. (2014). Capitalism and the emergent world order. International Affairs, 90(1), 71-91. https://doi.org/10.1111/1468-2346.12096

Blecker, R. A., Moreno-Brid, J. C., \& Salat, I. (2017). Trumping the NAFTA renegotiation: An alternative policy framework for Mexican-US cooperation and economic convergence. Real-World Economics Review, 94, 1-36. https://www.cepal.org/en/publications/42579-trumping-nafta-renegotiationalternative-policy-framework-mexican-united-states

Chase-Dunn, C., \& Gills, B. (2005). Understanding waves of globalization and resistance in the capitalist world system: social movements and critical global studies. Critical Globalization Studies, 45, 54-60. https://irows.ucr.edu/papers/irows12/irows12.htm

Checkel, J. T. (2017). Methods in Constructivist Approaches to International Security (SWP 55), 1-24. http://summit.sfu.ca/item/16812

Detraz, N. (2009). Environmental security and gender: Necessary shifts in an evolving debate. Security Studies, 18(2), 345-369. https://doi.org/10.1080/09636410902899933

Encyclopedia. (n.d). The anti-globalization movement. https://www.encyclopedia.com/socialsciences/news-wires-white-papers-and-books/antiglobalization-movement

Fuchs, C. (2015, December 10). Antiglobalization: Social movement. Encyclopaedia Britannica. https://www.britannica.com/event/antiglobalization

Fischer, R., Edward Halibozek, M. B. A., \& Walters, D. (2012). Introduction to security. Butterworth-Heinemann.

Guibernau, M. (2010). Migration and rise of the radical right. Policy Network Paper, 1, 1-19. 
https://esquerraeuropea.files.wordpress.com/2012/02/migrationandradicalright.pdf

Hammes, T. X. (2016, July). Will technological convergence reverse globalization? Strategic Forum, 297. $\quad$ https://ndupress.ndu.edu/Media/News/Article/834357/willtechnological-convergence-reverse-globalization/

Hannah-Fuchs, S. A. (2017). A brief history of the anti-globalization movement. Berlin: Deutsche Welle.

Husain, S. R. (2018). US-China trade spat weighs down the global crude economy. Daily Dawn. https://www.dawn.com/news/1426499

Hopgood, S. (2013). Human rights empire. In: The endtimes of human rights (pp. 119-141). Cornell University.

Ikenberry, G. J. (2018). The end of liberal international order? International Affairs, 94(1), 723. https://doi.org/10.1093/ia/iix241

Jorg-Flecker, G. H. (2016). Changing working life and the appeal of the extreme right. Routledge.

Jackson, R., Sørensen, G., \& Møller, J. (2019). Introduction to international relations: Theories and approaches. Oxford University.

Klaus, S. (2016). The fourth industrial revolution. In World Economic Forum (p. 11).

Khan, S. (2016). Transition from unipolar to a multipolar world: Implications for Pakistan's foreign policy. ISSRA Papers, 8(I), 1-16.

McGrew, A. G. (1992). Conceptualizing global politics. John Wiley.

Mozur, P. (2021, April 20). A global tipping point for reining in tech has arrived. The New York Times. https://www.nytimes.com/2021/04/20/technology/global-tipping-pointtech.html

Paul, B., \& Stares, Q. J. (2020). Perspectives on a changing world order. Council on Foreign Relations.

Pashakhanlou, A. H. (2014). Waltz, Mearsheimer and the post-Cold War world: The rise of America and the fall of structural realism. International Politics, 51(3), 295-315. https://link.springer.com/article/10.1057/ip.2014.16

Rewizorski, M. (2021). Backlash against globalisation and the shadow of Phobos. Fudan Journal of the Humanities and Social Science, 14(1), 123-141. https://link.springer.com/article/10.1007/s40647-020-00308-0

Ritzer, G., \& Dean, P. (2015). Globalization: A basic text. John Wiley.

Roubini, N. (2010). A Global Breakdown of the recession in 2009. http://www.forbes. com/2009/01/14/global-recession-2009-oped-cx_nr_0115roubini. html.

Kimball, W. Scott, R., E. (2014). China trade, outsourcing and jobs: Growing US trade deficit with China cost. Economic Policy Institute.

Sorensen, R. H. (2010). Introduction to international relations: Theories and approaches $\left(4^{\text {th }}\right.$ Edition). Oxford University.

Steger, M. B. (2017). Globalization: A very short introduction (Vol. 86). Oxford University.

Stiglitz, J. E. (2002). Globalization and its discontents (Vol. 500). Norton.

Global Trends. (2017). Global trends: Paradox of progress. National Intelligence Council.

Walter, S. (2021). The backlash against globalization. Annual Review of Political Science, 33, 1-36. https://doi.org/10.1146/annurev-polisci-041719-102405

Zumbrun, J. (2016). Forces that opened up borders show signs of sputtering. Wall Street Journal. 